\title{
Triada retoryczna (logos, etos, patos) a perswazyjność sylwetki prasowej
}

\section{Wstęp}

Sylwetka, czyli tekst sytuujący bohatera w centrum zainteresowania, jest współcześnie jednym z najpopularniejszych gatunków prasowych. Powody są różnorodnej natury. Po pierwsze, mimo przyrastających w szybkim tempie zasobów informacji, wciąż aktualna pozostaje redakcyjna zasada, głosząca, że ludzi najbardziej interesują inni ludzie - niepowtarzalne koleje ich losu, sukcesy i porażki zawodowe i osobiste. Po drugie, wiele postaci życia publicznego jest żywo zainteresowanych swoją obecnością w mediach, zatem gotowych jest intensywnie współpracować z dziennikarzami, często licząc również na osiągnięcie dzięki temu własnych celów. Po trzecie, specyfika gatunkowa sylwetki stwarza autorowi wyjątkowo szerokie możliwości, zarówno co do rozstrzygnięć formalnych, jak $\mathrm{i}$ artystycznego oraz perswazyjnego modelowania tekstu.

Rola ostatniego z wymienionych czynników jest szczególnie widoczna w perspektywie retorycznej, eksponującej perswazyjne walory form wypowiedzi, w przypadku sylwetki przejawiające się w wyraźnym oddziaływaniu na wszystkie główne sfery ludzkiej aktywności, tj. poznanie, odczuwanie i przeżywanie. Czytelnik, którego rozum, wola i uczucia powinny zostać zaangażowane w procesie poznawania i oceniania bohatera tekstu, staje się obiektem zabiegów autorskich odwołujących się do wiedzy, wyobraźni oraz empatii. Ich celem jest wykreowanie określonego wizerunku bohatera - zgodnie z przekonaniami lub doraźnym celem dziennikarza - który powinien zacząć funkcjonować w przestrzeni publicznej. Aby mógł się upowszechnić i utrwalić, należy nie tylko wzbudzić zainteresowanie czytelnika nieznanymi szerzej faktami, ale także poruszyć go poprzez aktywizowanie jego wyobrażeń o związku między myślą/zamiarem a czynem oraz wzbudzić (bądź okazać) uczucia, które pozwolą mu dzięki

*Dr hab., e-mail: mowors@uni.lodz.pl; Uniwersytet Łódzki, Wydział Filologiczny, Katedra Dziennikarstwa i Komunikacji Społecznej; 90-236 Łódź, ul. Pomorska 171/173. 
atrakcyjnemu przedstawieniu dostrzec w bohaterze sylwetki człowieka - mniej lub bardziej podobnego do czytelnika.

Czym jest wspomniane na początku ,sytuowanie bohatera w centrum zainteresowania"? Wiąże się ono z obligatoryjnym w przypadku sylwetki istnieniem pretekstu publikacji - najczęściej jest to nominacja na stanowisko, otrzymanie jakiegoś wyróżnienia, okrągła rocznica związana z życiem zawodowym lub prywatnym, a także fakt czyjejś śmierci lub przypadająca jej rocznica. Powód jest zatem związany z ważnym wydarzeniem zachodzącym w życiu najczęściej bardzo znanej osoby i ma to bezpośrednie konsekwencje dla opisu genologicznego tej formy wypowiedzi dziennikarskiej. Sylwetka jest bowiem gatunkiem mimetycznym, tj. naśladuje rozwiązania, które wypracowano na potrzeby innych form, sama nie wykształcając - jak dotąd - własnego, oryginalnego kształtu ${ }^{2}$. Z tego względu możliwie są jedynie arbitralne rozstrzygnięcia, czy mamy do czynienia np. z notatką poświęconą wydarzeniu związanemu z konkretną osobą lub wywiadem na jej temat, czy też z sylwetką w kształcie notatki lub wywiadu.

„Pasożytnicza” natura tego gatunku stwarza dziennikarzom bardzo szerokie możliwości kształtowania wizerunków bohaterów, a tym samym oddziaływania na czytelników. Pozostawanie w kręgu form informacyjnych skłania do skupiania się na faktografii (etapy edukacji, działalność zawodowa, społeczna lub artystyczna, wyróżnienia, umiejętności profesjonalne itd.), co czyni z prezentowanej osoby obiekt szczególnego „oglądu”, a czytającym pozwala ocenić, czy nominacja lub nagroda zostały słusznie przyznane. Wzmianka i notatka o czyjejś śmierci, zawierające elementy życiorysu, służą natomiast podkreśleniu straty, jaką ponoszą wszyscy, którzy dotychczas mogli korzystać z obecności i dokonań opisywanej postaci. Zdecydowanie bardziej osobista w tonie sylwetka-pożegnanie, pisana przez osobę bliską zmarłemu, eksponuje zaś wyjątkowość więzi z nim oraz rolę, jaką odegrał on w czyimś życiu. Wzruszenie i poczucie ubogacającego wpływu kontaktów międzyludzkich to najwyraźniejsze emocje, jakie towarzyszyć mogą lekturze takiego tekstu.

Publicystyczne ukształtowanie wypowiedzi pozwala autorom zarówno na wszechstronne wykorzystywanie źródeł, mozaikowe komponowanie wizerunku oficjalnego i prywatnego, „wielogłosowość” (wypowiedzi bohatera, osób mu życzliwych i nieprzychylnych oraz neutralnych, cytaty z dokumentów oficjalnych i osobistych itd.), jak i na posługiwanie się oryginalnym „kluczem” do rozszyfrowywania postaci, zaprezentowania jej w sposób niebanalny i odkrywczy. Demaskowanie, wzorcotwórczość, bilans życia, życzliwe promowanie, niechęć i admiracja - każda z tych strategii prezentacji może znaleźć zastosowanie w dziennikarskim portretowaniu.

\footnotetext{
${ }^{2}$ Por. M. Wojtak, Gatunki prasowe, Wydawnictwo UMCS, Lublin 2004, s. 120. Autorka dostrzega jednak autonomiczność gatunkową jednego z wariantów sylwetki-wspomnienia (zob. tamże, s. 130).
} 
Na potrzeby prezentowanych rozważań chciałabym ograniczyć sylwetkę do jej realizacji tekstowych o charakterze publicystycznym, jednak poświęconych zarówno znanym osobom żyjącym, jak i zmarłym. Pozwoli to prześledzić na wybranych przykładach, w jaki sposób autorzy kreują pożądany wizerunek bohatera w wymiarze logicznym, etycznym oraz patetycznym, a także ocenić, czy i jak na wykorzystywane przez nich sposoby oddziaływania perswazyjnego wpływa fakt, że bohaterem sylwetki może być osoba nieżyjąca. Pod uwagę zostaną wzięte zarówno teksty autorskie - obszerne, pogłębione publikacje adaptujące wzorzec artykułu publicystycznego lub gawędziarskiej opowieści, które można określić mianem portretów $w^{3}$, jak i współautorskie, tj. wywiady, publikowane w ostatnich latach przede wszystkim w kręgu tzw. prasy opinii ${ }^{4}$.

Kontekst genologiczny stanowią ustalenia zaprezentowane przez Marię Wojtak w jej Gatunkach prasowych. Autorka zwraca m.in. uwagę na dominantę gatunkową, którą w przypadku sylwetki wyznaczają aspekt pragmatyczny (przedstawienie i zarekomendowanie człowieka) i poznawczy (ukazanie charakterystyki w określonej perspektywie), oraz na obowiązującą regułę respektowania paktu faktograficznego ${ }^{5}$. Analizy materiału prasowego wskazują zaś na bogactwo stylistyczne poszczególnych realizacji tekstowych, wiążące się z rezygnacją z obiektywnego relacjonowania i sięganiem po wypowiedzi prezentowanej osoby ${ }^{6}$. Przyjmując taki punkt wyjścia, warto zastanowić się, jak dominująca pozycja jednego ze składników retorycznej triady - logosu, etosu czy patosu wpływa na ukształtowanie wizerunku bohatera tekstu.

Autorskiemu oddziaływaniu na intelekt czytelnika sylwetki służy głównie faktografia, dowodzenie bezpośrednie lub pośrednie oraz wnioskowanie. W interesujący sposób operowanie różnorodnymi szczegółami wyzyskała Barbara Pietkiewicz, tworząc portret Danuty Szaflarskiej’. Największa trudność pracy dziennikarskiej polegała na dotarciu do informacji o bardziej prywatnym charakterze, bowiem aktorka - mimo długoletniej kariery - wciąż pozostaje osobą tajemniczą, o której nawet koledzy wiedzą „tyle, co z prób”. Pietkiewicz uczyniła $\mathrm{z}$ tego braku danych oś konstrukcyjną tekstu, motywowi przewodniemu

\footnotetext{
${ }^{3}$ W żargonie dziennikarskim określenie ,portret” używane jest zamiennie z ,sylwetką"; w prezentowanym tu ujęciu przyjęto znaczenie węższe - tekst publicystyczny większych rozmiarów, wielostronnie prezentujący wybraną osobę, z wyraźnie zaznaczoną subiektywną opinią autora.

${ }^{4}$ Egzemplifikację zaczerpnięto z: „Polityki”, „Gazety Wyborczej”, „Press”, „Newsweeka Polska”.

${ }^{5}$ Zob. M. Wojtak, dz. cyt., s. 121.

${ }^{6}$ Por. tamże, s. $163-164$.

${ }^{7}$ B. Pietkiewicz, współpr. A. Mikołajczyk, W sprawie pierogów, „Polityka” 2007, nr 42, s. 78-80.
} 
nadając formę pytania - czy Szaflarska lubi pierogi. Niejako przy okazji poszukiwania odpowiedzi czytelnikowi zostają udostępnione niektóre fakty biograficzne, np. o zapadnięciu na tyfus, które doprowadziło do porzucenia szkoły handlowej dla studiów w Państwowym Instytucie Sztuki Teatralnej w Warszawie, czy o niezwykłej witalności, cechującej kobietę w zaawansowanym wieku. Paradoksalnie luki faktograficzne współtworzą także warstwę dokumentacyjną tekstu, bowiem osobami, które mogą o Szaflarskiej wiedzieć najwięcej są anonimowi „starszy aktor" i garderobiana. Konkretne dane - nazwy, nazwiska - pozbawione jednoznacznych odniesień czasowych pojawiają się w wyliczeniach, jak gdyby stanowiły jedynie element tła nieabsorbujący uwagi czytelnika:

I to był koniec wielkiej kariery filmowej. [...]. Raz wystąpiła na zdjęciach próbnych w kufajce: karykatura Halinki, profanacja Krysi ze „Skarbu”, proletariackich trzeba nam twarzy, towarzysze, nie salonowych. Jeszcze Podstolina w „Zemście” nakręconej przez Bohdziewicza. Jeszcze rola w „Dziś w nocy umrze miasto”, w „Ludziach z pociągu”, w „Domu bez okien”.

Ten szczególny niedostatek faktów mógłby na prawach kontrastu eksponować opinie wyrażane expressis verbis - tych jest jednak w sylwetce niewiele („fantastyczna koleżanka”, „,bardzo dobry człowiek”, „,absolutna kobieta”, „ktoś absolutnie bez żółci”), podobnie jak autocharakterystyki Szaflarskiej. Wizerunek aktorki wyłania się zatem z dziennikarskiej narracji, w której można rozpoznać emocje, jakie bohaterka wzbudza w Pietkiewicz - zauroczenie, podziw, ale też chęć rozwikłania tajemnicy wybitnej, ale niewystarczająco docenianej artystki, co dziennikarka podkreśla w zakończeniu portretu. Mimo prób wielostronnego spojrzenia, pozostaje on wciąż niedokończonym, ale ciekawym szkicem, w którym domysły i wrażenia odgrywają istotniejszą rolę niż wyraziste oceny.

Zupełnie inny efekt perswazyjny w podobnych warunkach, tj. braku dostatecznie szczegółowych informacji, osiągnęła Małgorzata Wyszyńska, prezentując sylwetkę Tomasza Niewidomskiego, który w październiku 2013 roku został nowym wydawcą „Przekroju”. Pod znaczącym tytułem Niewiadome autorka powiązała opowieść o człowieku z opisem niejasnej sytuacji legendarnego tygodnika. Sformułowaniom, takim jak: ,podobno kilka lat temu”, „branża zna go słabo” czy „nie znam szczegółów”, budującym atmosferę niepewności co do oceny dotychczasowych dokonań fotografa-biznesmena, w drugiej części tekstu odpowiadają uwagi o niedowierzaniu, z jakim branża przyjęła informacje o kwocie transakcji sprzedaży „Przekroju”, o anonimowych analitykach mediów, komen-

\footnotetext{
${ }^{8}$ Tamże, s. 79.

${ }^{9}$ M. Wyszyńska, Niewiadome, „Press” 2013, nr 11, s. 34-37.
} 
tujących tę sprawę i trudnościach z uzyskaniem precyzyjnych odpowiedzi na pytania o kierunek zmian, jakie Niewiadomski zamierza wprowadzić w tygodniku. Wizerunek bohatera tekstu wzmacnia i uzasadnia zatem wyrażane przez dziennikarkę przekonanie, iż „nie wiadomo na razie, o czym nowy »Przekrój« będzie ani kiedy się o tym dowiemy"10. Wiedza uzyskana przez czytelnika w trakcie lektury okazuje się wystarczająca jedynie do ugruntowania wątpliwości co do całej zaprezentowanej sytuacji.

Powyższych obserwacji nie należy jednak interpretować w sposób sugerujący, że wyjątkowa dbałość o bogactwo dokumentacyjne i wiarygodność faktów w sylwetce gwarantują sukces autorski. Przeciwnie - mogą doprowadzić do tego, że w portrecie zbyt silnie zacznie się ujawniać poetyka życiorysu i biogramu ${ }^{11}$. Podobny skutek może przynieść zbyt skrupulatne stosowanie reguły dowodzenia na mocy świadectwa. Autorzy sylwetek regularnie zamieszczanych w miesięczniku „Press” niemal nie formułują opinii, które nie byłyby wsparte cytatami słów osoby portretowanej, a częściej kogoś, kto miał okazję dobrze ją poznać. W ten sposób często uwiarygodniane są nawet fakty:

Stawki oferowane przez Dunina autorom tekstów nigdy nie są duże, choć zawsze płaci. - Sam pisze za friko, żeby pula na honoraria dla autorów była większa - mówi Kazimierz Malinowski. Team autorski składał się z kilkunastu osób, w dużej części młodych. Dla wielu pieniądze są sprawą drugorzędną. - Stawiałem pierwsze kroki w pisaniu i cieszyłem się, że mogę zrobić wywiad czy napisać recenzję - opowiada Stanisław Łubieński ${ }^{12}$.

Kreowany wizerunek sprawia wrażenie ogólnie uporządkowanego zestawu cudzych sądów, a ściślej - jednoznacznych ocen autora, których słuszności „dowodzą" precyzyjnie dobierane cytaty. Tak prowadzona opowieść o człowieku jest jednak mało spójna, narzuca niemal wyłącznie logiczne rozstrzygnięcia: prawda - fałsz, do minimum ograniczając rolę czytelniczej empatii oraz samodzielnego wyprowadzania wniosków. Obraz oryginalnej osobowości i wyjątkowych losów przesłania rachunek faktów.

Umiejętne zastosowanie właściwie wyselekcjonowanych danych zazwyczaj charakteryzuje sylwetki wyróżniające się także cennym walorem, jakim jest niebanalny koncept prezentowania bohatera. Jest on szczególnie ważny w przypadku osób, które od dawna cieszą się zainteresowaniem dziennikarzy i były wielokrotnie opisywane lub takich, które aktualnie zwracają powszechną uwagę. Rozwiązanie warte odnotowania w tym kontekście zastosowała Aleksandra

\footnotetext{
${ }^{10}$ Tamże, s. 37.

${ }^{11}$ Zob. M. Wojtak, dz. cyt., s. 143-144.

12 A. Niziołek, Neron, czyli Dunio, „Press” 2012, nr 1, s. 56.
} 
Krzyżaniak-Gumowska w „kulinarnym” portrecie Wojciecha Modesta Amaro pt. Momenty z Amaro $^{13}$. Oryginalny „,klucz do postaci” autorka zdradza już w lidzie: „W swojej restauracji zamiast dań serwuje momenty. Najróżniejsze momenty w życiu Wojciecha Modesta Amaro doprowadziły do tego historycznego dnia dla polskiej gastronomii, kiedy dostał gwiazdkę przewodnika kulinarnego Michelina”" Każdy z kolejnych pięciu „momentów” rozpoczyna się identycznie - od krótkiego opisu smakowanej przez autorkę potrawy. Dalszą część tworzy zaś relacja z przełomowego zdarzenia w biografii bohatera lub opis pośrednio charakteryzującej go sytuacji. Razem tworzą szereg argumentacyjny, który prowadzi czytelnika do wniosku, że Amaro swój sukces zawdzięcza pasji i pracy - to dzięki nim stał się artystą tworzącym rzeczy niepowtarzalne. Dlatego tych kilka tytułowych „momentów” wystarcza, by czytelnik zrozumiał, że mówią one o bohaterze więcej niż długa, biograficzna opowieść.

Perswazyjne oddziaływanie w obszarze etosu skupia się wokół aksjologii i postawy moralnej, wpływać ma zatem na wolę czytelnika. Szczególnym punktem odniesienia jest w takim przypadku jego pamięć, w której dziennikarz chce zaszczepić bądź utrwalić własne przekonania, zazwyczaj wspomagając ten proces odwołaniami do uczuć i wyobrażeń. Dobrą egzemplifikacją takich zabiegów są tzw. sylwetki-pożegnania, jednak nie w swej najbardziej typowej postaci - krótkiego tekstu informacyjnego, powiadamiającego czytelników o śmierci znanej osoby oraz wyliczającego jej najważniejsze dokonania, lecz wypowiedzi osobistej, będącej wyrazem głębokiego żalu, poczucia straty, a także złożeniem hołdu ${ }^{15}$. Czytelnicy mogą być wręcz zaskoczeni intymnością wyznania, ale służy ona uwiarygodnieniu prezentowanych ocen, a może także zostać wykorzystana dla efektu artystycznego - jak w tekście Marty Konarzewskiej opublikowanym po śmierci dziennikarki radia TOK Fm Anny Laszuk:

Kiedy umarła, pomalowałam jej paznokcie. Na perłowo. Lubiła perłowe lakiery. Odgarnęłam jej włosy z czoła i zobaczyłam, jak twarz powoli zaczyna młodnieć. Sekunda za sekundą, rok za rokiem, wstecz, wstecz. Stanowczo. Jak by się chciało zawrócić do początku, choć przecież się wie, że nie można.

W tym biegu w tył Ania zatrzymała się na trzydziestce, jej twarz miała znowu tyle lat. Wiek, kiedy wiele można, lecz jest się na tyle dojrzałą, by wiedzieć, że „wiele” nie znaczy „wszystko”, dlatego lepiej sięgać po wszystko. Zawsze sięgała po wszyst-

${ }^{13}$ A. Krzyżaniak-Gumowska, Momenty z Amaro, „Newsweek Polska” 2013, nr 13, s. 42-44.

14 Tamże, s. 42.

15 To rozumienie odbiega od klasyfikacji M. Wojtak (zob. tejże, dz. cyt., s. 123-128) - więcej zob. hasło sylwetka w: „Zagadnienia Rodzajów Literackich” 2010, nr 1-2 (105-106), t. 53, s. 295-297. 
ko. Była skora do ugody, lecz nie do kompromisu. Była pogodnie zadziorna i zawsze stawiała na swoim ${ }^{16}$.

Żegnając swoją przyjaciółkę i współpracowniczkę, autorka nie tylko wprost wyraża opinie, ale wyprowadza je z obserwacji faktów. Laszuk jako autorka książek, artykułów, komentatorka w radiu pokazywała, na czym polega zdecydowanie, potrzeba działania, dostrzeganie tego, co należy zmieniać na lepsze. Jednak ważniejsza od profesjonalizmu była jej postawa człowieka zaangażowanego, bo - jak cytuje Konarzewska - „Nie można siedzieć cicho”"17. W ten sposób autorka eksponuje wzorzec, z którego mogą skorzystać inni, zadaniem sylwetki-pożegnania jest bowiem podkreślenie tego, czego śmierć nie unicestwia. Poczucie straty może więc zostać przedefiniowane i stać się dla czytelników źródłem mobilizacji do uczynienia własnego życia równie głębokim i pełnym treści jak życie Laszuk.

O ile jednak w przypadku sylwetek-pożegnań, a także - przynajmniej w pewnym stopniu - sylwetek-wspomnien ${ }^{18}$ zazwyczaj można mówić o skrępowaniu autorów konwencją stosownego mówienia o zmarłych, to w przypadku tekstów współautorskich konflikt natury aksjologicznej i światopoglądowej bywa dużo wyraźniejszy. Jako przykłady mogą posłużyć dwa wywiady Jacka Żakowskiego - z Dorotą Rabczewską (Dodą) ${ }^{19}$ i Kubą Wojewódzkim² ${ }^{20}$. W obu dziennikarz jest bardzo aktywnym dyskutantem, usiłującym przekonywać rozmówców do swoich racji i kontropiniować ich sądy, w obu też każdy z interlokutorów przyjmuje określoną rolę, co prowadzi do mocnego zderzenia stanowisk. Żakowski jednoznacznie opowiada się za angażowaniem się ludzi w otaczający ich świat, za nieustannym wysiłkiem rozumienia zachodzących w nim zjawisk oraz odpowiedzialnością za czyny i słowa. Jednak znana piosenkarka, demonstrująca świadomie egoistyczny i hedonistyczny system wartości, zgodny z jej wykreowanym wizerunkiem publicznym, wydaje się zupełnie odrzucać jego argumenty, dopóki dziennikarz nie uświadomi jej (jak można sądzić - przypadkowo), że w Polsce obowiązują zwyczaje i przepisy, które mogą ograniczać jej prywatne wybory lub dotykają ważnych dla niej spraw. Choć zaskoczona, Rabczewska nie rezygnuje jednak ze swojego przekonania, że „lepiej nie wiedzieć”, bo według niej wiedza rodzi złe emocje, stres, a szanse, by coś zmienić na lepsze, są niewielkie. Jej credo: „Świat kręci się wokół mnie. Nie ja wokół świata. Kreuję sobie własną rzeczywistość i świetnie się w niej czuję. Reszta mnie nie interesuje"21 pozostaje

\footnotetext{
${ }^{16}$ M. Konarzewska, Siegała po wszystko, „Gazeta Wyborcza” 2012, 15.10, s. 2.

17 Tamże.

${ }^{18}$ Teksty dotyczące osób zmarłych, publikowane w dłuższy czas po śmierci, najczęściej w rocznicę zgonu - por. hasło sylwetka, dz. cyt.; M. Wojtak, dz. cyt., s. 128-130.

${ }^{19}$ Zderzenie światów, z D. Rabczewską rozm. J. Żakowski, „Polityka” 2012, nr 17/18, s. 36-39.

${ }^{20}$ Ja jednak myślę, z K. Wojewódzkim rozm. J. Żakowski, „Polityka” 2012, nr 27, s. 25-27.

${ }^{21}$ Zderzenie..., dz. cyt., s. 36.
} 
w mocy i dla części czytelników może brzmieć atrakcyjnie. Nie znaczy to jednak, że portret piosenkarki jest aktem niezgody publicysty na wyrosły z egocentryzmu utylitaryzm, to raczej tytułowe „zderzenie światów” i zachęta do zastanowienia się, co mówi ono o współczesnej rzeczywistości i czy światy te mogą ze sobą współistnieć ${ }^{22}$.

Wywiad z Kubą Wojewódzkim w większym stopniu natomiast mieści się w poetyce sporu - rozmówcy próbują się wzajemnie przekonać, gdzie przebiegają granice publicznej prowokacji, na którą może sobie pozwolić satyryk. Dla Żakowskiego oburzenie, jakie często wywołuje swoimi wypowiedziami Wojewódzki to przede wszystkim powód do refleksji i próby zrozumienia sytuacji, dla kontrowersyjnego celebryty - dowód nierozumienia konwencji, braku zdrowego rozsądku i hipokryzji w życiu publicznym. W rozmowie Wojewódzki stara się wymodelować swój wizerunek tak, by obnażyć prymitywizm stereotypowego myślenia, dlatego zarówno składa deklaracje (np. ,[...] dla mnie popularność jest narzędziem, nie celem. Wierzę, że mogę zmieniać świat na lepsze swoją metodą uprawiania humoru i słowa” ${ }^{23}$, „Mnie bycie zabawnym coraz mniej obchodzi. A coraz bardziej interesuje mnie sens mojej obecności”24), jak i polemizuje, sięgając po metodę ataku personalnego, wartościowania przyczyn i skutków, kontrprzykładów. Odwołuje się także do poczucia sprawiedliwości i uczciwości wobec samego siebie, które nie pozwalają mu bez zastrzeżeń poddawać się publicznym żądaniom przeprosin: „Ja przepraszam bez żadnego ale. Czuję, że przegięliśmy. Ale nie chcę przepraszać jako rasista, ksenofob, szowinista, który się zdemaskował. Chcę przepraszać jako zawodowy błazen, któremu żart się nie udał" ${ }^{25}$. Spór Żakowskiego z Wojewódzkim staje się dla czytelnika sporem o interpretację faktów w kontekście jednostkowej i społecznej wrażliwości oraz o postawę przejawianą w życiu publicznym. I choć pozostaje nierozstrzygnięty, pokazuje inny niż powszechnie znany wizerunek popkulturowego celebryty. Miejsce złośliwego cynika i megalomana zajął inteligentny dyskutant, który potrafi odwoływać się do wartości bez szyderstwa i konsekwentnie domaga się widzenia zjawisk w ich właściwym wymiarze, bez ulegania manipulacji. Występując w roli oskarżonego, broni się także erystyką, ale nie sięga po środki nieetyczne, co w tym przypadku należy interpretować jako okoliczność sprzyjającą budowaniu jego wiarygodności.

$$
\text { * } \quad * \quad *
$$

22 J. Żakowskie podejmuje ten problem w rozmowie z psychologiem społecznym J. Czapińskim już w kolejnym numerze „Polityki” (zob. Zderzenie pokoleń, z J. Czapińskim rozm. J. Żakowski, „Polityka” 2012, nr 19, s. 20-22).

${ }^{23}$ Ja jednak..., dz. cyt., s. 26.

${ }^{24}$ Tamże, s. 27.

25 Tamże. Chodzi o wypowiedź o Ukrainkach w programie J. Wojewódzkiego i M. Figurskiego Poranny $W-F$ w radiu Eska Rock 21 czerwca 2012 r. 
Działania perswazyjne w trzecim wymienionym obszarze - patosu - koncentrują się na okazywaniu i wzbudzaniu uczuć, stanów wzruszenia i pobudzaniu wyobraźni ożywiającej emocje. To oddziaływanie silnie wspierające pouczony intelekt i poruszoną wolę czytelnika, świadczy bowiem o głębi przeżyć twórcy, odsłaniających jego ludzką naturę. Dzięki temu np. zrekonstruowana na podstawie tekstu więź łącząca autora $\mathrm{z}$ bohaterem sylwetki może uruchomić mechanizm współodczuwania, a zatem zwiększyć szanse skutecznej perswazji. Taką metodę oddziaływania zastosowała wspomniana już Barbara Pietkiewicz, prezentując skomplikowane życie Andrzeja Samsona, psychologa i terapeuty oskarżonego o pedofilię i zmarłego w marcu 2009 roku. Tekst pt. Szklanych kulek już nie ma opublikowany został wkrótce po jego śmierci, ale nie ma bezpośredniego, publicystycznego celu: rozstrzygnąć o winie czy niewinności Samsona. Autorka wielokrotnie podkreśla, że to niemożliwe, bo sprawy nie da się ująć jedynie w paragrafy kodeksu karnego. Artykuł jest raczej próbą wniknięcia w naturę zdarzeń składających się na historię zniszczonego życia psychologa. Pietkiewicz nieustannie przechodzi od zdroworozsądkowego tłumaczenia do stawiania pytań, od współodczuwania rozmaitych emocji do świadomości bólu, zawodu i rezygnacji, pozostałych po traumatycznych wydarzeniach. Pisze tak, aby gra emocjami była obecna, ilekroć zmienia punkt odniesienia, dzięki temu nie pozwala zamknąć się w żadnej z ról: dziennikarki, badaczki, kobiety, znajomej Samsona. Czytelnik zaś musi podążać jej tropem, skupiony nie na faktach, ale na ich przeżywaniu:

Znajomi przyprowadzili do Samsona 6-letnią córkę. Jej młodszy brat zapadł na uporczywą chorobę i odtąd rodzice zajęli się tylko nim, zaniedbując Hanię. Zaczęła sikać do łóżka i bić psa. Aż znaleźli ją raz na balkonie skostniałą z zimna. Też chciała zachorować na nerki.

Na sikających miał własny patent. Na stole w jego mieszkaniu stała miska pełna szklanych, kolorowych kulek. Weź jedną - mówił - połóż pod poduszkę, a wtedy na pewno się w nocy nie zsikasz. Albo dawał dziecku misia. Chyba powiesz mu, czemu jesteś smutny, co u ciebie w ogóle słychać. Leczone od dawna bez skutku lejki, jak je nazywał, budziły się suche. Rodzicom Hani dał receptę prostą: mają się na powrót serdecznie nią zająć, bo wyrośnie z nienawiścią do brata. Pogadał z nią raz i drugi. Dobrze było ${ }^{26}$.

W sposobie prowadzenia narracji przez Pietkiewicz można dostrzec szczególną determinację, będącą efektem całej gamy uczuć - wstrętu do „rozszarpujących" człowieka tabloidów i rozczarowania postawą osób, które mogłyby wystąpić w jego obronie, lecz tego nie uczyniły, spokoju zrodzonego ze świadomości, że cierpienie Samsona już się skończyło, podziwu dla talentu i sukcesów

${ }^{26}$ B. Pietkiewicz, Szklanych kulek już nie ma, ,Polityka” 2009, nr 13, s. 24. 
psychologa, zawodu, że przypadkowe zdarzenia doprowadziły do tragicznego finału. To zaangażowanie autorki nie pozostawi czytelnika obojętnym, zostanie mu niemal narzucone, czyniąc odczytanie sylwetki złożonym procesem, w którym fakty nieuwikłane w żywe emocje stają się niemal niezrozumiałe i przestają podlegać wartościowaniu.

Szklanych kulek już nie ma nie jest ani typową sylwetką-pożegnaniem, ani tradycyjnym wspomnieniem, niemniej wymiar perswazyjny tekstu jest wyraźny - chodziło o domknięcie publicznej dyskusji na temat znanego psychoterapeuty. Publikacja była głosem w obronie sprawiedliwej oceny człowieka i miała również uświadomić czytelnikom złożoność sytuacji, która we wcześniejszych medialnych opisach została uproszczona i zafałszowana.

\section{Zakończenie}

Przywołane przykłady ukazują dziennikarski portret jako gatunek o wielkim potencjale ekspresji autorskiej, której podporządkowane są warstwa faktograficzna, porządek fabularny, strategia wartościowania, model argumentacji. W tym znaczeniu jest to forma zbliżona do reportażu, a nawet eseju - wykraczająca poza zwyczajowe oczekiwania czytelnika i stawiająca mu wyzwanie. Wizerunek bohatera opiera się bowiem przede wszystkim na niepowtarzalnym, jednostkowym sposobie postrzegania oraz oceniania go, który nie musi (a raczej: nie powinien) respektować obrazu osoby istniejącego w świadomości społecznej. Dziennikarz niczym reportażysta odkrywa „nieznane” i jak eseista przygląda się obiektowi swojego zainteresowania. Jeśli - jak w sylwetce w kształcie wywiadu - ma możliwość, niejako w obecności czytelnika, skonfrontowania swoich wyobrażeń o bohaterze z rzeczywistością, może próbować wpływać na niego tak, by spełnił on jego oczekiwania. Jeśli w sylwetce-pożegnaniu autor daje wyraz swojemu stanowi emocjonalnemu, to również po to, by zademonstrować charakter wyjątkowej więzi, która łączyła go ze zmarłą osobą. Perswazyjność portretu zawsze zatem ma swe źródło w jednoczesnym oddziaływaniu tego, co czytelnik interpretuje jako obiektywnie istniejące (wypowiedzi osób trzecich, faktografia), oraz tego, co autor ujawnia jako własne doświadczenie lub wrażenie. Zachwianie proporcji tych elementów może uczynić wizerunek zbyt formalnym lub subiektywnie przerysowanym.

Krzysztof Mroziewicz określił felieton mianem „teatru jednego dziennikarza"; wydaje się, że przynajmniej niektóre realizacje sylwetek zasługują na określenie „przedstawienie według jednego dziennikarza”. Oddaje ono zarówno cel publikacji, czyli umożliwienie czytelnikowi poznania kogoś, jak i wyraźne piętno indywidualizmu autora, pozwalające na swobodne odwoływanie się do logosu, 
etosu i patosu. Z punktu widzenia oddziaływania perswazyjnego każda $\mathrm{z}$ tych sfer może być równie użyteczna, pozwala bowiem na nawiązanie do tego, co nieuchronnie łączy wszystkich ludzi, a zatem również dziennikarza, bohatera i czytelnika.

\section{Bibliografia}

Ja jednak myślę, z K. Wojewódzkim rozm. J. Żakowski, „Polityka” 2012, nr 27, s. 25-27.

Konarzewska M., Sięgała po wszystko, „Gazeta Wyborcza” 2012, 15.10, s. 2.

Krzyżaniak-Gumowska A., Momenty z Amaro, „Newsweek Polska” 2013, nr 13, s. 42-44.

Niziołek A., Neron, czyli Dunio, „Press” 2012, nr 1, s. 56.

Pietkiewicz B., Szklanych kulek już nie ma, „Polityka” 2009, nr 13, s. 22-25.

Pietkiewicz B., współpr. A. Mikołajczyk, W sprawie pierogów, „Polityka” 2007, nr 42, s. 78-80.

Sylwetka [hasło], „Zagadnienia Rodzajów Literackich” 2010, nr 1-2 (105-106), t. 53, s. 295-297.

Wojtak M., Gatunki prasowe, Wydawnictwo UMCS, Lublin 2004.

Wyszyńska M., Niewiadome, „Press” 2013, nr 11, s. 34-37.

Zderzenie pokoleń, z J. Czapińskim rozm. J. Żakowski, „Polityka” 2012, nr 19, s. 20-22.

Zderzenie światów, z D. Rabczewską rozm. J. Żakowski, „Polityka” 2012, nr 17/18, s. 36-39.

\section{Monika Worsowicz}

\section{The Rhetorical Triad (Logos, Ethos, Pathos) and the Persuasiveness of Piece in the Press}

\section{(Summary)}

The article discusses the specificity of character pieces (the journalistic genre for the presentation and recommendation of a person) in the context of the rhetorical triad. Logos, ethos and pathos are three ways of shaping an argument which in a character piece have a persuasive impact on the reader by influencing his intellect, will and emotions. In journalistic practice, this means using facts and commanding direct or indirect inference in relation to the axiology of moral attitudes, as well as showing and engendering feelings, states of emotion and stimulating the imagination. The author discusses these actions based on selected journalistic texts from the magazines Polityka, Gazeta Wyborcza, Press and Newsweek Polska.

Key words: portrait, press, rhetoric, logos, ethos, pathos. 